\title{
Evaluation of Physical, Anatomical, and Biometric Characteristics of Citrus sinensis Trees in Longitudinal and Transverse Axes of Stem
}

\begin{abstract}
Ali Hassanpoor Tichi, ${ }^{\mathrm{a}, *}$ Habibollah Khademieslam, ${ }^{\mathrm{b}}$ and Mojtaba Rezanezhad Divkolae
Three healthy Citrus sinensis (orange) trees in Babol, Iran, were randomly selected and cut. Two discs of $5 \mathrm{~cm}$ thickness were prepared along the tree (breast height and crown). In the transverse direction, the test specimens were cut $2 \times 2 \mathrm{~cm}$ to $3 \mathrm{~cm}$ from the pith to the bark sequentially and examined. The biometric and physical properties were measured, and microscopic sections of wood near the bark were studied using light microscopy according to the International Association of Wood Anatomists' (IAWA) List. Anatomical examination of the C. sinensis wood showed that the species was a diffuse porous hardwood, with indistinct growth rings, simple perforation plates, alternate intervessel pits, and banded parenchyma. The basic density and oven-dry density increased from the pith towards the tree bark and from the bottom of the tree towards the crown. There was a significant difference in both the transverse and longitudinal directions of the $C$. sinensis tree in terms of fiber length, fiber lumen diameter, fiber diameter, and cell wall thickness. The mean fiber length, fiber diameter, fiber lumen diameter, and cell wall thickness were $0.76 \mathrm{~mm}, 23.64 \mu \mathrm{m}, 9.23 \mu \mathrm{m}$, and $14.41 \mu \mathrm{m}$, respectively.
\end{abstract}

Keywords: Orange wood; Basic density; Diffuse porous hardwood

Contact information: a: Department of Wood Science and Engineering, Technical Faculty of No. 2, Mazandaran Branch, Technical and Vocational University (TVU), Sari, Iran; b: Department of Wood and Paper Science and Technology, Faculty of Natural Resources and Environment, Science and Research Branch, Islamic Azad University, Tehran, Iran; *Corresponding author: hasanpoortichi@gmail.com

\section{INTRODUCTION}

Wood is a renewable resource and one of the most consumed industrial materials. Wood was one of the first materials used by humans and has played an important role in human development. Wood and paper mills must ascertain the basic characteristics of the wood, including its physical, anatomical, and biometrical properties, because they greatly influence the yield of factories, the quality of products, and functional features. Because wood is a biological material, all its properties vary in different parts of the stem. Therefore, it is important to know how these changes occur in different parts of the tree stem. Due to high demand for wood products, the irregular cutting and disappearance of forests, and the breathing plan for the northern forests of Iran, the wood and paper industries have been suffering from a shortage of raw materials. Right now due to the lack of forest woods and given that in Iran citrus trees are mostly found in the north of country, especially in Mazandaran province, it makes sense to utilize the wood of the Citrus sinensis tree. To date, extensive investigations have not been done on the wood of $C$. sinensis tree.

Hassanpoor Tichi et al. (2020). "Citrus sinensis wood," BioResources 15(3), 5696-5709. 5696 
Sweet orange tree with the scientific name of $C$. sinensis from the Sapindales order, Rutaceae family and Citrus genus is an evergreen tree that is in leaf during the year. $C$. sinensis is grown in the rain forest and guinea savannah (Olife et. al. 2015). The orange tree is a small, spiny tree, typically growing to $7.5 \mathrm{~m}(25 \mathrm{ft})$, but occasionally reaching heights up to $15 \mathrm{~m}$ (50 ft), generally with a compact crown (Vogel 2003). The C. sinensis tree is self-fertile. The suitable $\mathrm{pH}$ for this species is acid, neutral, and alkaline soil but it can grow in $\mathrm{pH}$ from highly acid to highly alkaline in clay, loam, and sandy soils. The $C$. sinensis tree grows to $9 \mathrm{~m}$ and prefers well-drained moist soils and full sunshine. The proper temperature for $C$. sinensis trees during the growing season is between 12/7 to 37/7 ${ }^{\circ} \mathrm{C}$ and $1 / 6$ to $10{ }^{\circ} \mathrm{C}$ for the dormant season.

Eromosele (2016) studied the anatomy of a $C$. sinensis tree trunk concerning vessels and rays. The average length and diameter of the vessels were $213.07 \mu \mathrm{m} \pm 35.64 \mu \mathrm{m}$ and $69.35 \mu \mathrm{m} \pm 13.87 \mu \mathrm{m}$, respectively, with an average ray height of $313.65 \mu \mathrm{m} \pm 62.02 \mu \mathrm{m}$ and an average ray width of $44.87 \mu \mathrm{m} \pm 23.30 \mu \mathrm{m}$. There was no significant difference between the mean lengths of the vessels in the longitudinal and transverse axes of the tree, but there was a significant difference between the median diameters of the vessels in the longitudinal and transverse axes of the tree. The diameter of the vessels decreased from stump to tree crown. The pith increased toward the bark. Additionally, there was no significant difference among the mean heights of the rays in the longitudinal axis (lower, middle, and upper regions) of the trunk, but there were slight differences in the average lengths of the rays in the transverse direction. In contrast, there was a significant difference in the transverse direction in the diameters of the rays, with the width of the rays increasing from the pith to the bark. In terms of cross-sectional structure, this species has axial parenchyma of multiple rows, solitary vessel pores and multiples of 3 or 4 , the ends of which are open and short and have heterogeneous rays.

Tichi and Divkolae (2019) investigated the anatomical, physical, and biometrical properties of wood near the pith and bark of Ficus carica trees at three heights. The fiber length, fiber lumen diameter, fiber diameter, and cell wall thickness decreased from the pith toward the bark and downward from the tree to the crown. Other physical properties (basic density, oven-dry density, and tangential and radial shrinkage) increased from pith to bark.

Aliabadi et al. (2011) investigated the dimensions of hornbeam fibers in the Astara region of Iran. With increasing distance from the pith and approaching the bark, the length, diameter, and thickness of the fiber walls significantly increased. The greatest values of fiber length, diameter, and thickness were $1.509 \mathrm{~mm}, 23.93 \mu \mathrm{m}$, and $3.897 \mu \mathrm{m}$, respectively.

Saeedi et al. (2017) examined the biometric, physical, and chemical properties of Iranian oak and concluded that the physical and biometric properties increased radially from the pith to the bark. The fiber length near the pith was $807 \mu \mathrm{m}$ and near the bark was $1073 \mu \mathrm{m}$. The fiber diameter near the pith was $16.7 \mu \mathrm{m}$ and near the bark was $17.9 \mu \mathrm{m}$. The fiber lumen diameter near the pith was $3.6 \mu \mathrm{m}$ and near the bark was $3.9 \mu \mathrm{m}$. The dry densities for the pith, middle, and bark parts were $0.93 \mathrm{~g} / \mathrm{cm}^{3}, 0.99 \mathrm{~g} / \mathrm{cm}^{3}$, and $1.12 \mathrm{~g} / \mathrm{cm}^{3}$, respectively. The basic densities were $0.84 \mathrm{~g} / \mathrm{cm}^{3}, 0.91 \mathrm{~g} / \mathrm{cm}^{3}$, and $0.98 \mathrm{~g} / \mathrm{cm}^{3}$, respectively. Therefore, this study investigated the physical, anatomical, and biometric characteristics of $C$. sinensis trees in the longitudinal and radial axes of the stem. 


\section{EXPERIMENTAL}

\section{Materials and Methods}

In order to examine the physical, anatomical, and biometric characteristics, three healthy $C$. sinensis trees (without any mechanical and biological damage and other defects) were selected and cut from the plantation in the Babol area of Mazandaran province, Iran. All $C$. sinensis trees were grown at the elevation range of 2 to 50 meters above sea level with annual temperature average of $17 / 1{ }^{\circ} \mathrm{C}$ and annual rainfall average of $799 \mathrm{~mm}$ and located at between $36^{\circ} 34^{\prime} 15^{\prime \prime} \mathrm{N}$ and $52^{\circ} 44^{\prime} 20^{\prime \prime} \mathrm{E}$. The height of the $C$. sinensis trees was $3 \mathrm{~m}$, and the average diameter was $30 \mathrm{~cm}$. Then in the harvested stems, $5 \mathrm{~cm}$ thick disks were taken at two different height level of trees (breast height and near the crown). Next, each disc was sequentially cut into $2 \mathrm{~cm} \times 2 \mathrm{~cm}, 3-\mathrm{cm}$-long specimens from the pith towards the tree bark (Fig. 1). All test specimens have moisture content of $70 \%$ after cutting. They were transferred to Sari Wood \& Paper Laboratory of Shahid Hashemi Nejad Technical University (with temperature of $20{ }^{\circ} \mathrm{C}$ and relative humidity of $65 \%$ ) for biometric, physical, and anatomical experiments.

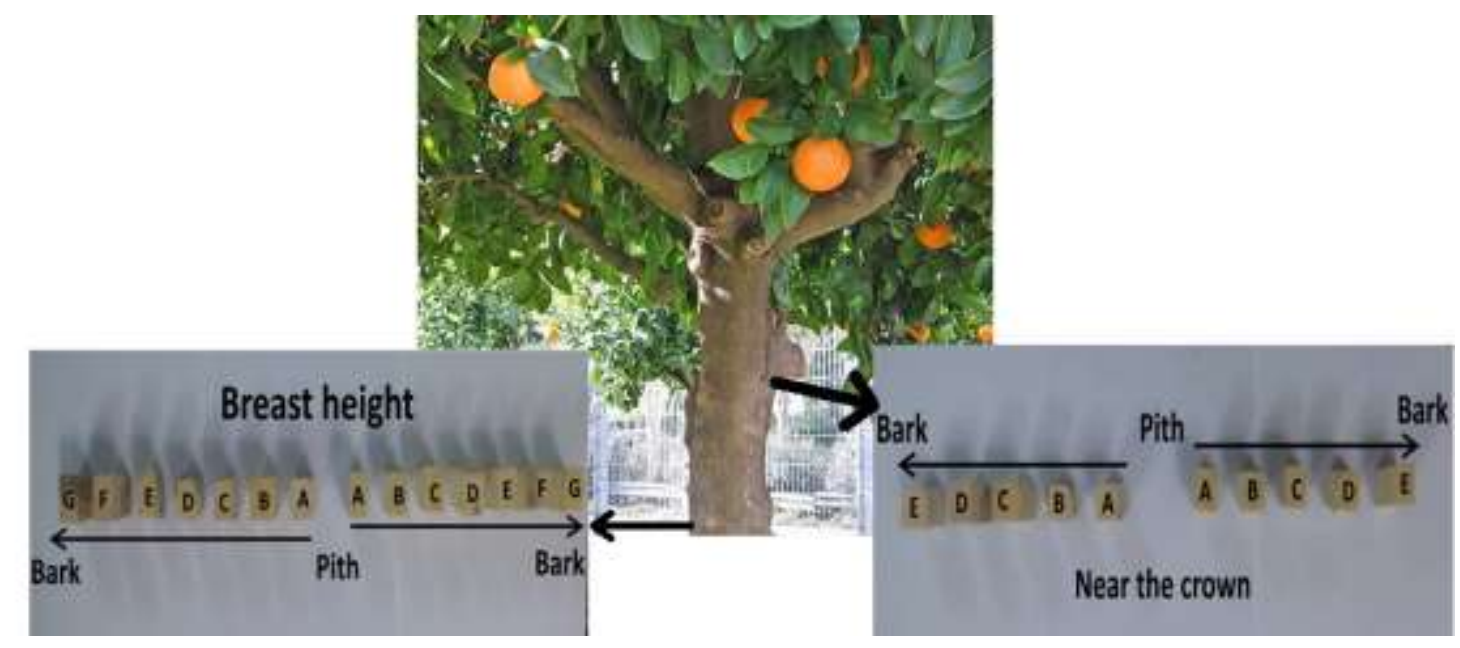

Fig. 1. Cut patterns and number of test specimens at two tree heights

\section{Preparation of Microscopic Sections}

The $2 \mathrm{~cm} \times 2 \mathrm{~cm}, 3$-cm-long specimens were prepared for detailed examination of the anatomical properties of the wood near the pith according to the International Association of Wood Anatomists (IAWA) (Wheeler et al. 1989). To soften the wood texture, pre-cut specimens were immersed in warm water and glycerol for $10 \mathrm{~d}$ in a ratio of 1:1. A microtome was used to prepare in triplicate (transverse, tangential, and radial) microscopic thin sections. They were immersed in warm water to open the folds. The microscopic section was incubated in bleach for $15 \mathrm{~min}$ to $30 \mathrm{~min}$ to remove intracellular contents, and the section was rinsed with distilled water to eliminate the odor of bleach. Next, the sections were stained with safranin/astra-blue dual staining solution for $0.5 \mathrm{~min}$, $3 \mathrm{~min}$, and $5 \mathrm{~min}$ and then dehydrated and replaced with 50\%, 75\%, and $96 \%$ alcohols, respectively. Samples were washed and placed in xylene solution. Finally, each section was mounted on a slide. A light microscope equipped with a graduated eyepiece was used for anatomical studies of the near-bark region (Parsapajouh and Schweingruber 2001). 


\section{Preparation of Samples for Measuring the Biometric Properties of Fibers}

The Franklin method was used for fiber separation (Franklin 1945). To measure the biometric properties of the fibers from the specimens prepared from the two tree heights (Fig. 2), $10 \mathrm{~mm} \times 15 \mathrm{~mm}$ thick wood chips were prepared in a 2-mm-thick tangential direction. The chips were inserted into a test tube, and the sample code was labeled on the test tube. Then, a mixture of acetic acid and hydrogen peroxide was poured onto test tube. After the white specimens were bleached inside the test tube, they were washed with distilled water 5 to 6 times, washed, and stained with safranin. The fibers were fixed on the slides after separation, and at least 30 fibers from each slice were randomly measured by light microscope using a scanning lens. Fiber length was measured using 10x magnification. Fiber lumen diameter, fiber diameter, and cell wall thickness were measured with a magnification of $40 \times$.

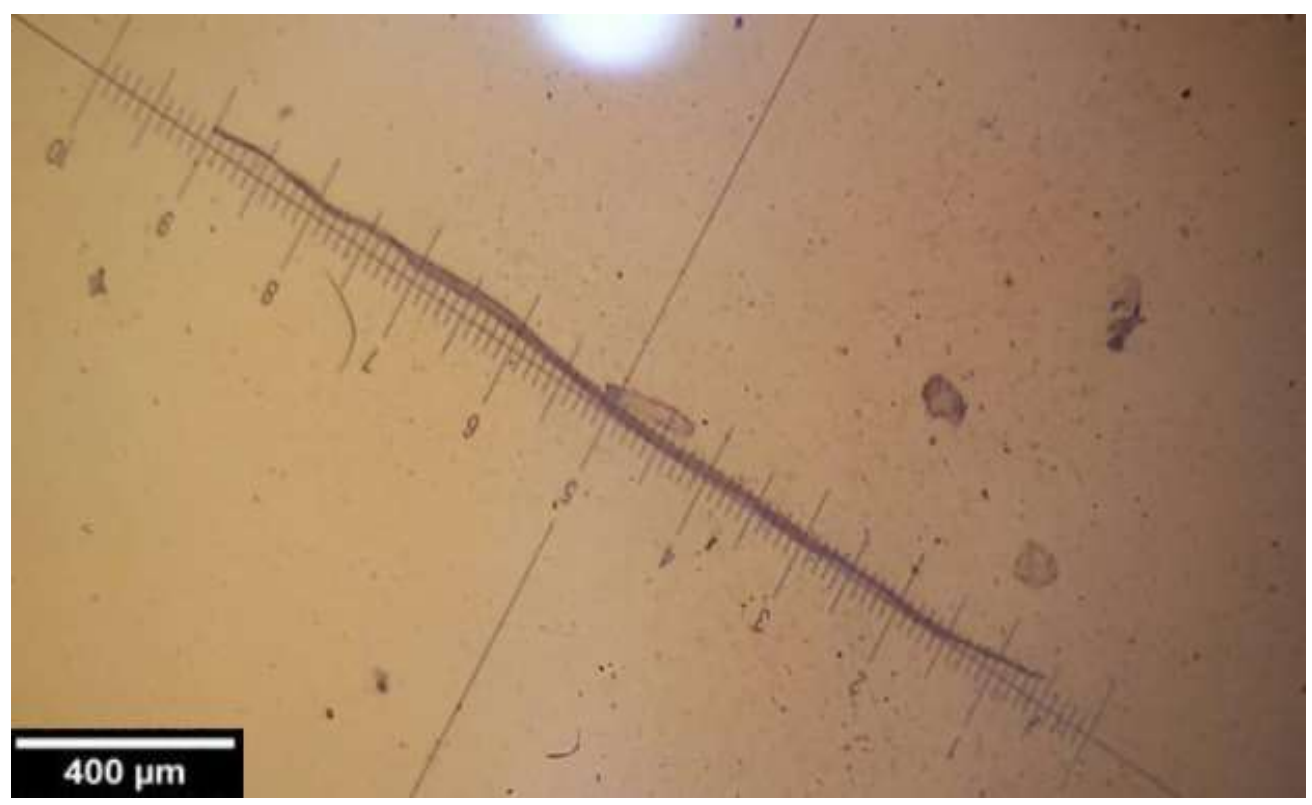

Fig. 2. Measuring fiber biometric properties

\section{Measuring Physical Properties}

Physical properties of the $C$. sinensis tree wood, including basic density and ovendry density, were calculated in accordance with ISO-13061-2 (2014) in dimensions (tangential $\times$ radial $\times$ longitudinal) of $2 \mathrm{~cm} \times 2 \mathrm{~cm} \times 3 \mathrm{~cm}$. A cross-sampling method was used to measure the density change. The orthotropic and geometrical axes in the samples were completely matched. To measure wood density, the samples were immersed in water for one week to completely saturate them with water, and then they were weighed with a precision of $0.001 \mathrm{~g}$. The dimensions were measured in the longitudinal, tangential, and radial directions using a digital caliper with $0.01-\mathrm{mm}$ accuracy. The samples were placed in an oven at $103{ }^{\circ} \mathrm{C} \pm 2{ }^{\circ} \mathrm{C}$ for $24 \mathrm{~h}$, and then their weights and secondary dimensions were measured. Basic density was calculated by dividing dry weight by saturated volume, and dry density was calculated by dividing dry weight by dry volume.

\section{Statistical Analyses}

Statistical analyses were performed using Statistica software (version 13, Dell Inc., Round Rock, TX, USA) at a significance level of $\alpha=0.05$. The obtained results were 
analyzed statistically, and an analysis of variance (ANOVA) was performed to determine the significance of the tested parameter. A Duncan's multiple range test (DMRT) was performed to compare treatment means.

\section{RESULTS AND DISCUSSION}

\section{Microscopic Characteristics}

The most important anatomical properties of the wood near the bark of the $C$. sinensis species were examined according to the list of microscopic features of the International Association of Wood Anatomists (IAWA) (Table 1). Microscopic examination of the $C$. sinensis tree transversely revealed that this species was a diffuse porous hardwood species, with indistinct growth rings, presence of tyloses in the vessel lumen, and axial parenchyma in bands more than three cells wide. The vessel grouping and its arrangements were mainly solitary pores (pores which generally are not in contact with other pores) and radial groups (two to three pores attached radially). Cluster vessels were also observed in this species (Fig. 3). At the tangential section, ray width was 1 to 4 cells (often 3 to 4) and ray height was 16 to 13 cells. The pits between the lateral walls of the vessels were alternate (Fig. 4). At the radial section, this species was mostly homogeneous wood rays (all the ray cells are procumbent rectangularly), but there were also heterogeneous wood rays (body ray cells procumbent with one row of upright and/or square marginal cells) in this wood. This species has simple perforation plates and vessel-ray pitting: vessel-ray pits with distinct borders; similar to intervessel pits in size and shape throughout the ray cell (Figs. 5 and 6).

\section{Biometric Properties}

As the tree height increased, the mean fiber length decreased. The longest fiber length at breast height was $0.76 \mathrm{~mm}$ in sample $\mathrm{G}$ (near the bark), and the shortest fiber length in the crown area in sample A (near the pith) was $0.65 \mathrm{~mm}$. Fiber length decreased from the tree bark (sample G) to the pith (sample A) at two tree heights (Fig. 7A). With increasing tree height from breast height to tree crown, mean fiber cell wall thickness decreased. The maximum average cell wall thickness at breast height in the bark area (sample G) was $14.41 \mu \mathrm{m}$, and the minimum average cell wall thickness in the crown area of the pith (sample A) was $9.97 \mu \mathrm{m}$. Cell wall thickness decreased from the tree bark to the tree pith (Fig. 7B). The changes in the fiber diameter in the transvers direction of the tree from the bark (sample $\mathrm{G}$ ) to the pith (sample A) at two heights of the tree were descending. The greatest mean fiber diameter at breast height in sample $\mathrm{G}$ was $23.64 \mu \mathrm{m}$, and the lowest fiber diameter of the tree fibers in sample A was $16.03 \mu \mathrm{m}$ (Fig. 7C). The fiber diameter also varied at the two tree heights, decreasing from breast height to the tree above (Fig. 7C). 
Table 1. Characteristics of Citruses Based on the List of the International Association of Wood Anatomists (IAWA) (Wheeler et al. 1989)

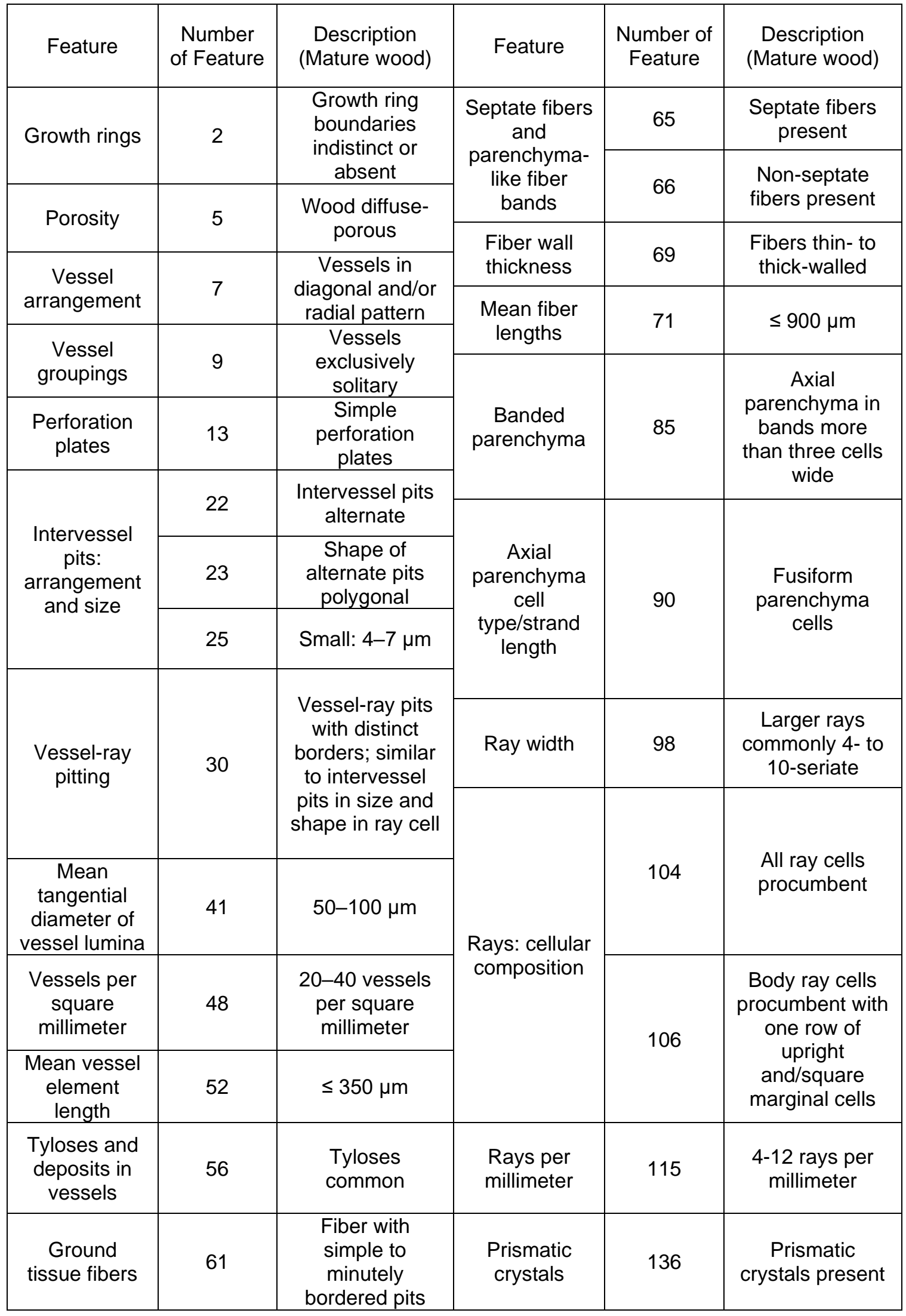




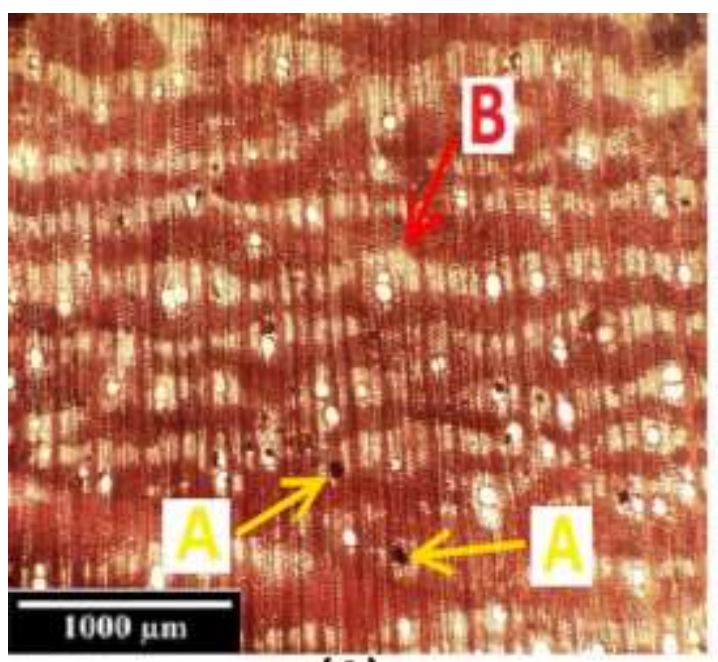

(A)

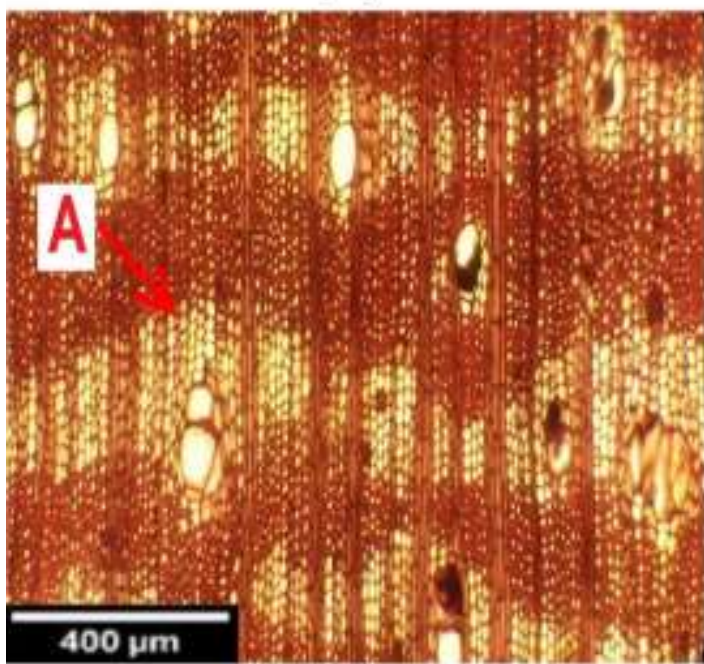

(C)

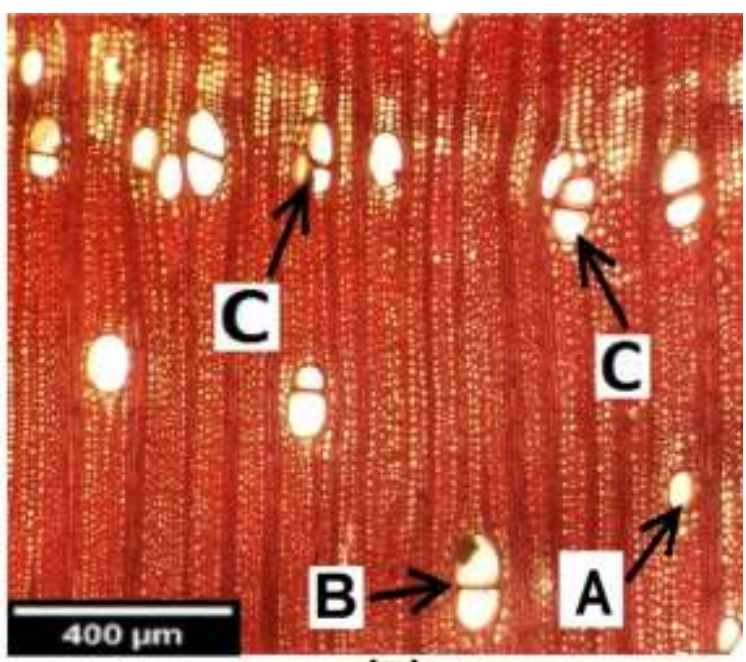

(B)

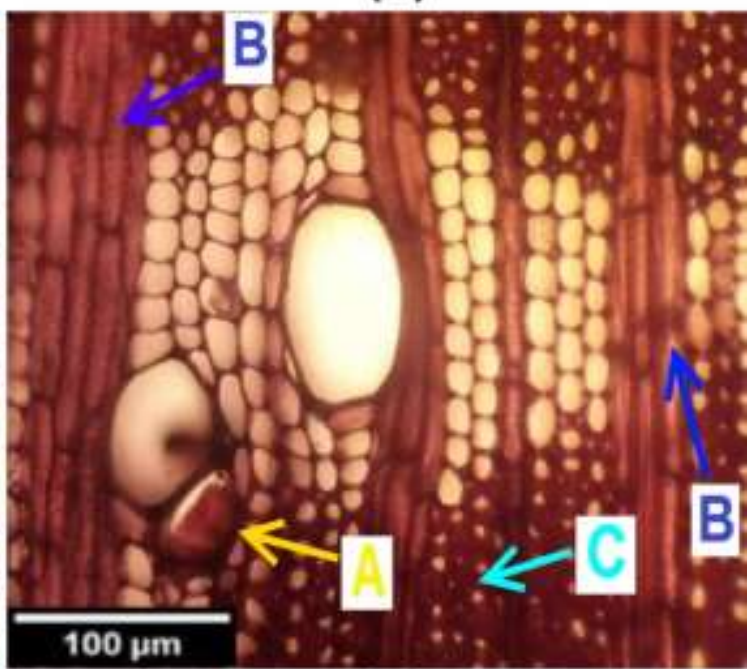

(D)

Fig. 3. Cross-sections of Citrus sinensis trees: $(A)$ presence of tyloses in the vessel lumen (arrow A) and axial parenchyma in bands more than three cells wide (arrow B); (B) solitary vessel pores (arrow A), vessels in diagonal and/or radial pattern (arrow B), and vessel clusters (arrow C); (C) axial parenchyma in bands more than three cells wide (arrow A); and (D) presence of tyloses in the vessel lumen (arrow A), ray width of 3 cells to 4 cells (arrow B), and fiber lumen cells(arrow $C$ ) 


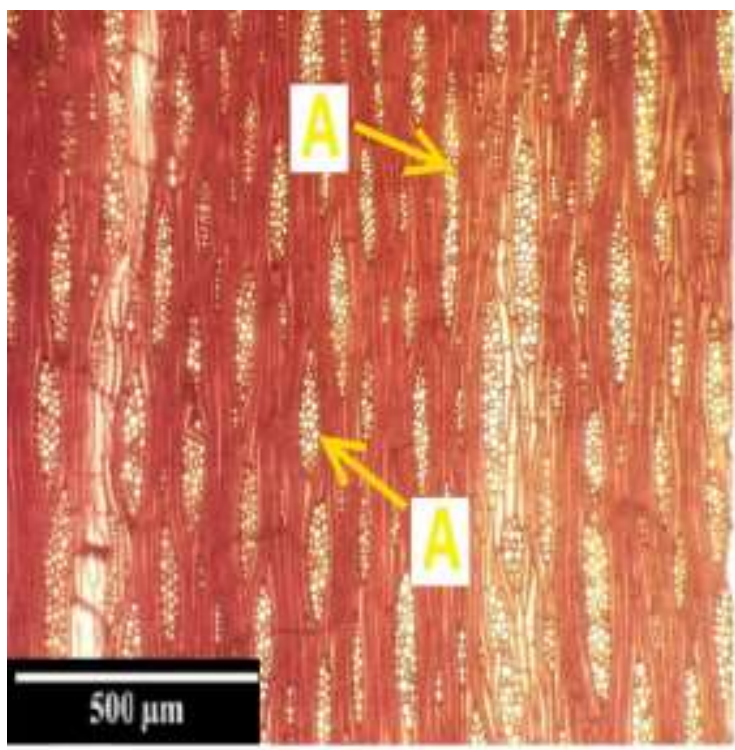

(A)

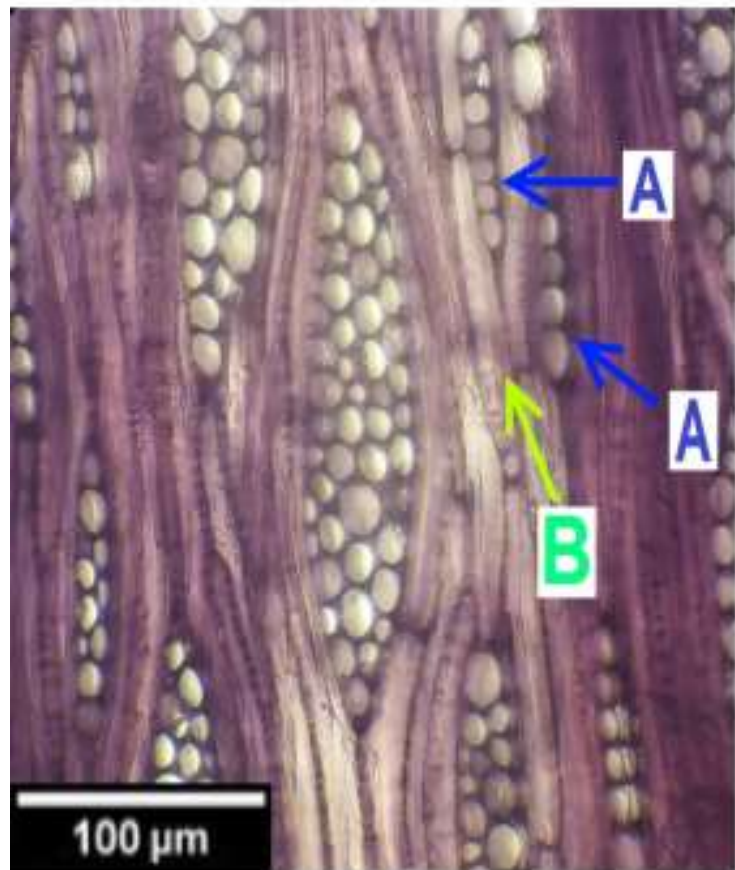

(C)

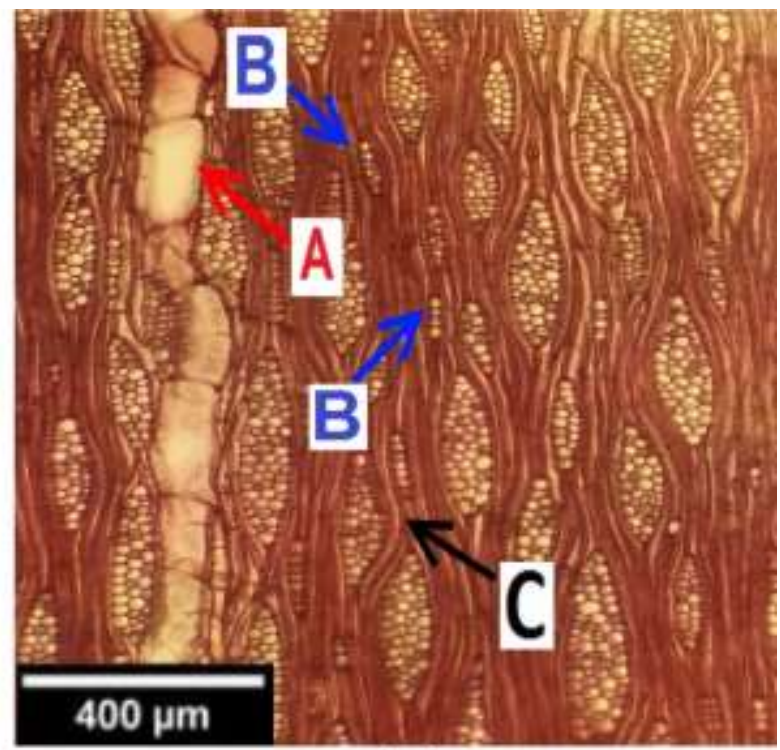

(B)

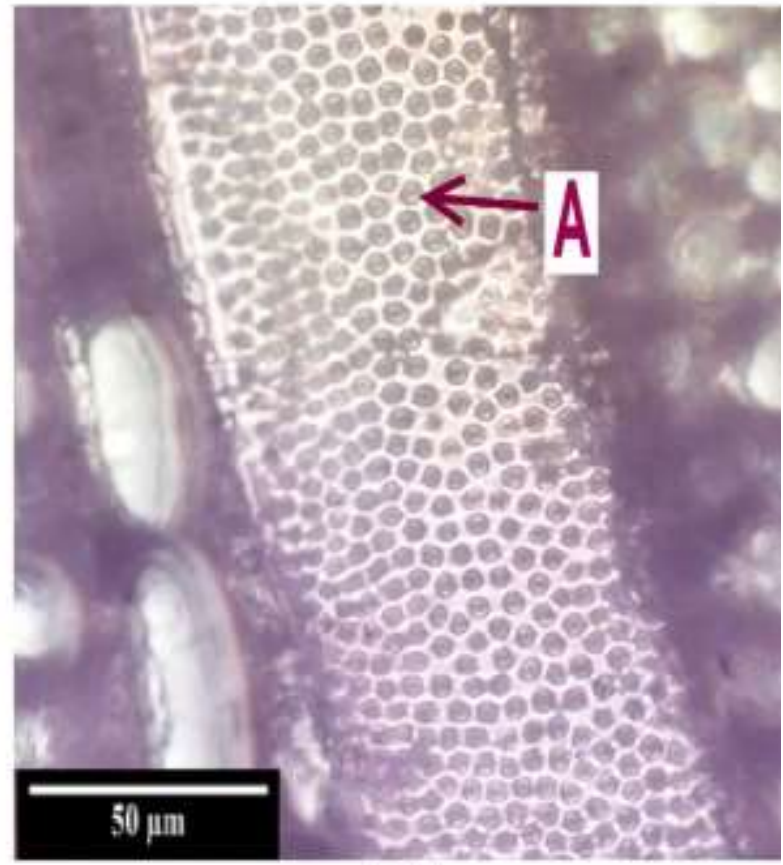

(D)

Fig. 4. Tangential sections of the $C$. sinensis trees: $(A)$ Ray width of 3 cells (arrow $A$ ); (B) vessel cells (arrow $A$ ), uniseriate rays (arrow $B)$, and non-septate fibers (arrow $C) ;(C)$ uniseriate rays (arrow A) and septate fibers (arrow B); and (D) intervessel pits alternate (arrow A) 


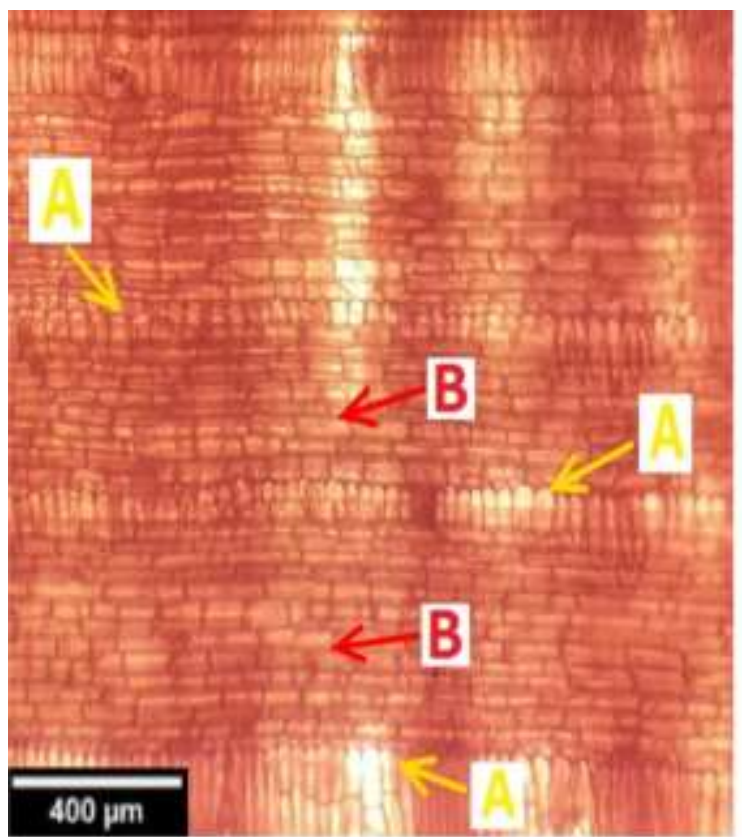

(A)

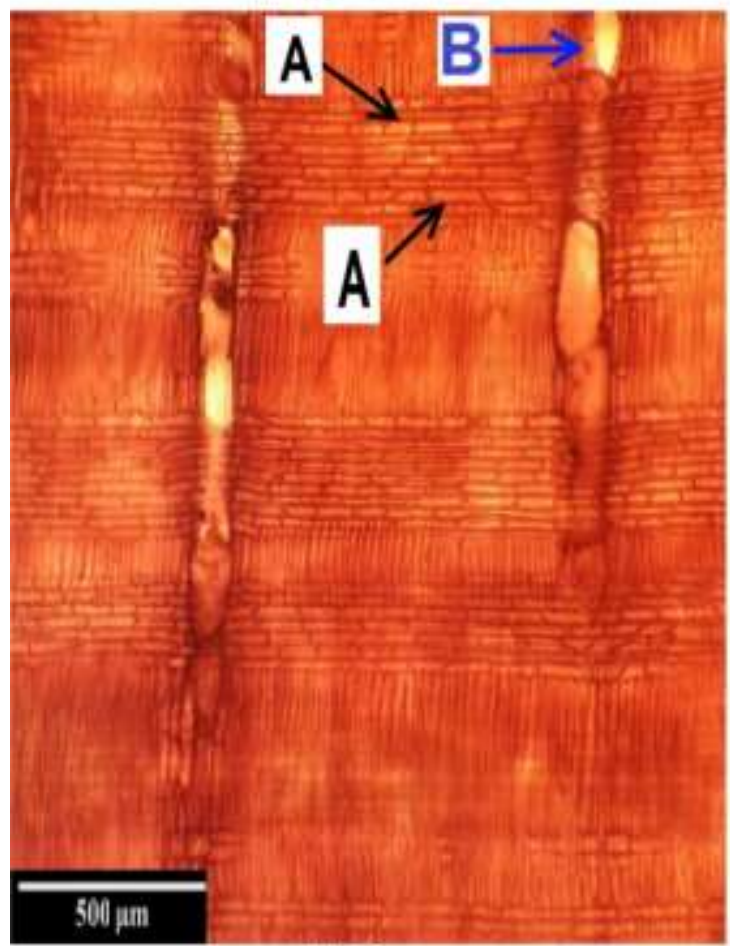

(C)

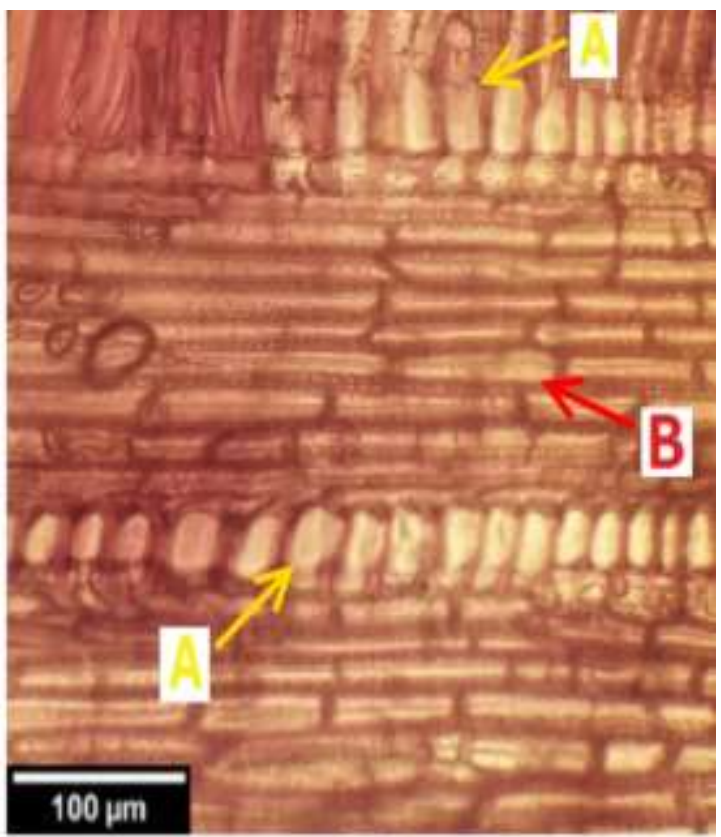

(B)

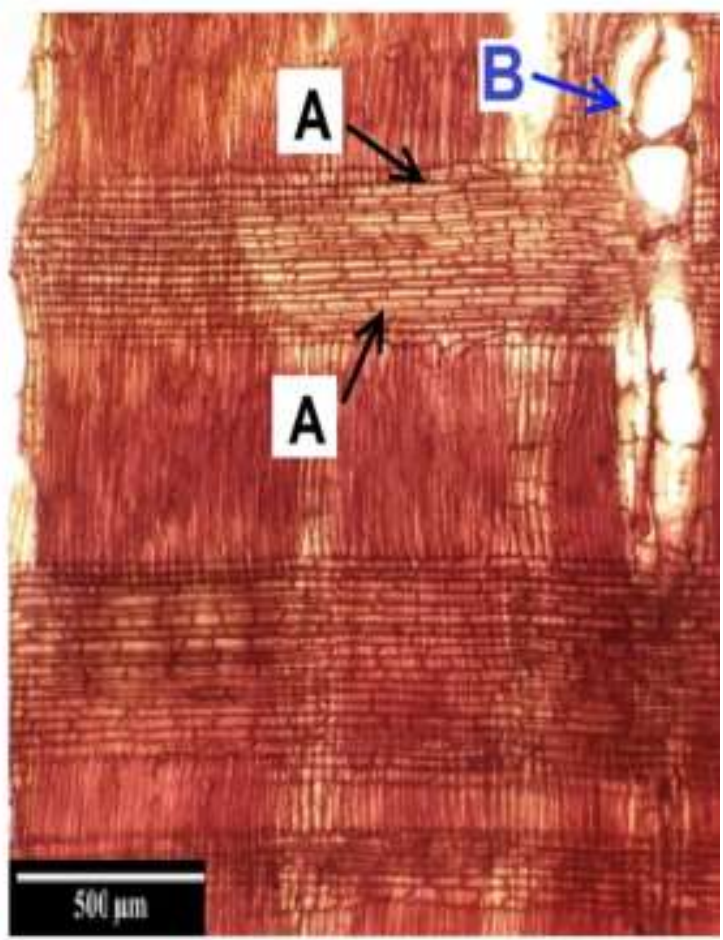

(D)

Fig. 5. Radial sections of the $C$. sinensis trees: ( $A$ and $B$ ) heterogeneous rays (body ray cells procumbent with one row of upright and/or square marginal cells), upright rectangularly (arrow $A$ ), and procumbent rectangularly (arrow $B) ;(C$ and $D)$ homogeneous rays (all the ray cells are procumbent rectangularly), procumbent rectangularly (arrow A), and simple perforation plates (arrow B) 


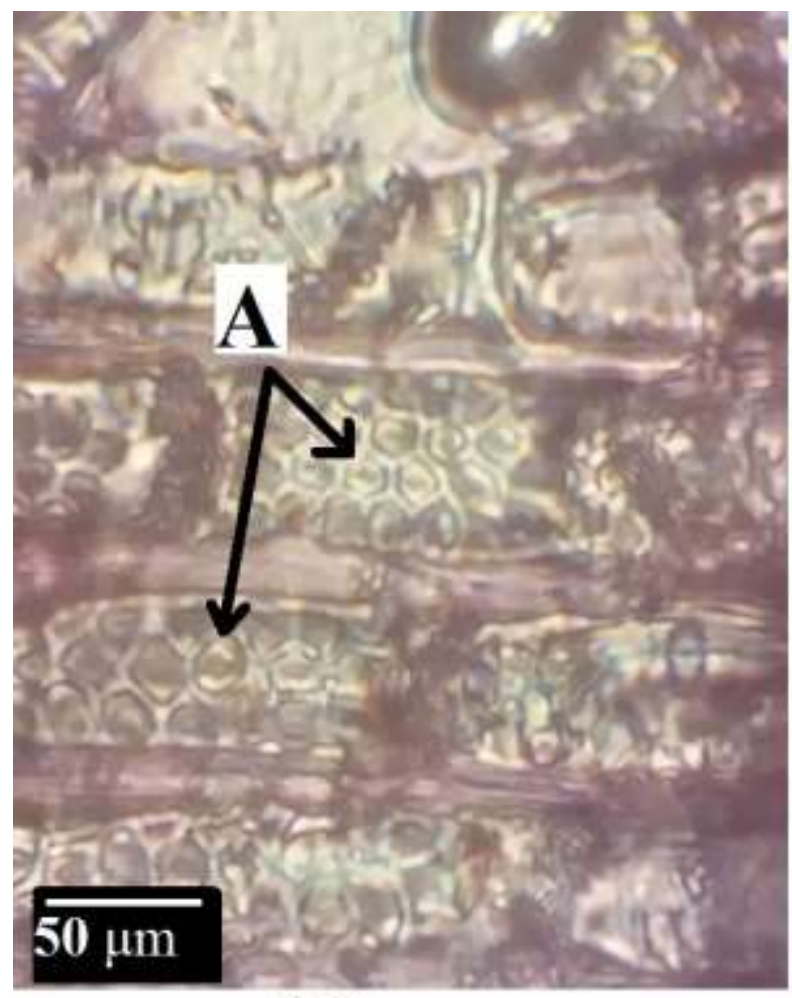

(A)

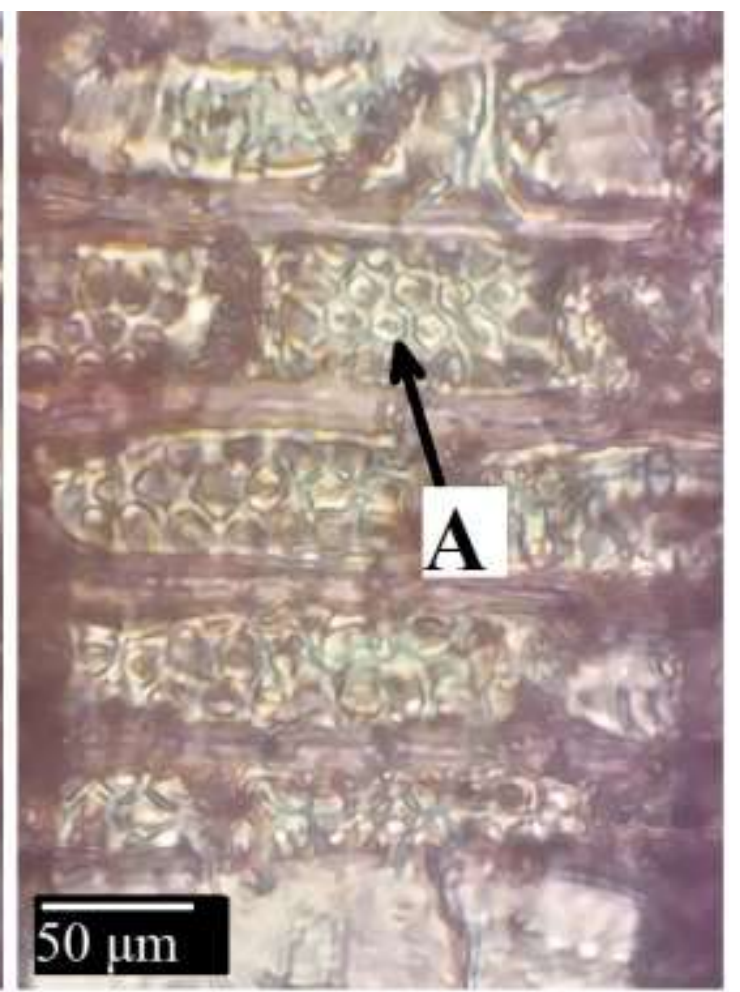

(B)

Fig. 6. Radial sections of the $C$. sinensis trees: $(A$ and $B)$ pits between rays and vessel cells with distinct borders, similar to intervessel pits in size and shape throughout the ray cell (arrow $A$ )

As the height of the tree increased from breast height to the top of the tree (tree crown), the mean fiber lumen diameter decreased. The greatest mean fiber lumen diameter at breast height in the bark area (sample G) was $9.23 \mu \mathrm{m}$, and the minimum mean fiber lumen diameter at the crown was $6.06 \mu \mathrm{m}$. The fiber lumen diameter increased from the pith to the bark (Fig. 7D).

Factors that increase the fiber dimensions include the age of the cambium, and there is a linear relationship between fiber length and cambium age. As the tree age increases, the fiber dimensions also increase (Zobel and van Buijtenen 1989; Zobel and Sprague 1998; Nosrati et al. 2015). Wood fibers in the pith area have decreased length, fiber diameter, fiber lumen diameter, and cell wall thickness compared to near-bark wood fibers. This result is due to the activity of mother cambium cells (fusiform initials) in the juvenile wood and mature wood areas. As the tree ages, the mother cells of the cambium evolve to become larger. Consequently, within the range of the bark, including mature wood, the wood fibers are taller, larger, and thicker (Adamopoulos and Voulgaridis 2002; Marsoem et al. 2002).

Fiber length, fiber lumen diameter, fiber diameter, and cell wall thickness decreased in the longitudinal direction of the tree with increasing tree length from at breast height to tree crown. The main reason for the decrease in the dimensions of the fibers in the crown part of the tree compared to those in the lower part of the tree was the presence of juvenile wood in the upper part of the tree (Zobel and Sprague 1998; Mahdavi et al. 2004). Biometrical properties are one of the most important factors for wood and paper industry mills and especially for the pulp and paper industry. For this reason, it is important to pay 
attention to these features (such as fiber length, fiber lumen diameter, fiber wall thickness, fiber diameter), because these factors are correlated with the yield of mills. With these changes, it is concluded that the length of the fibers at the bottom of the tree (breast height) is longer than at the top of the tree (near the crown). As a result, the lower part of the trunk will be suitable for the paper industry.
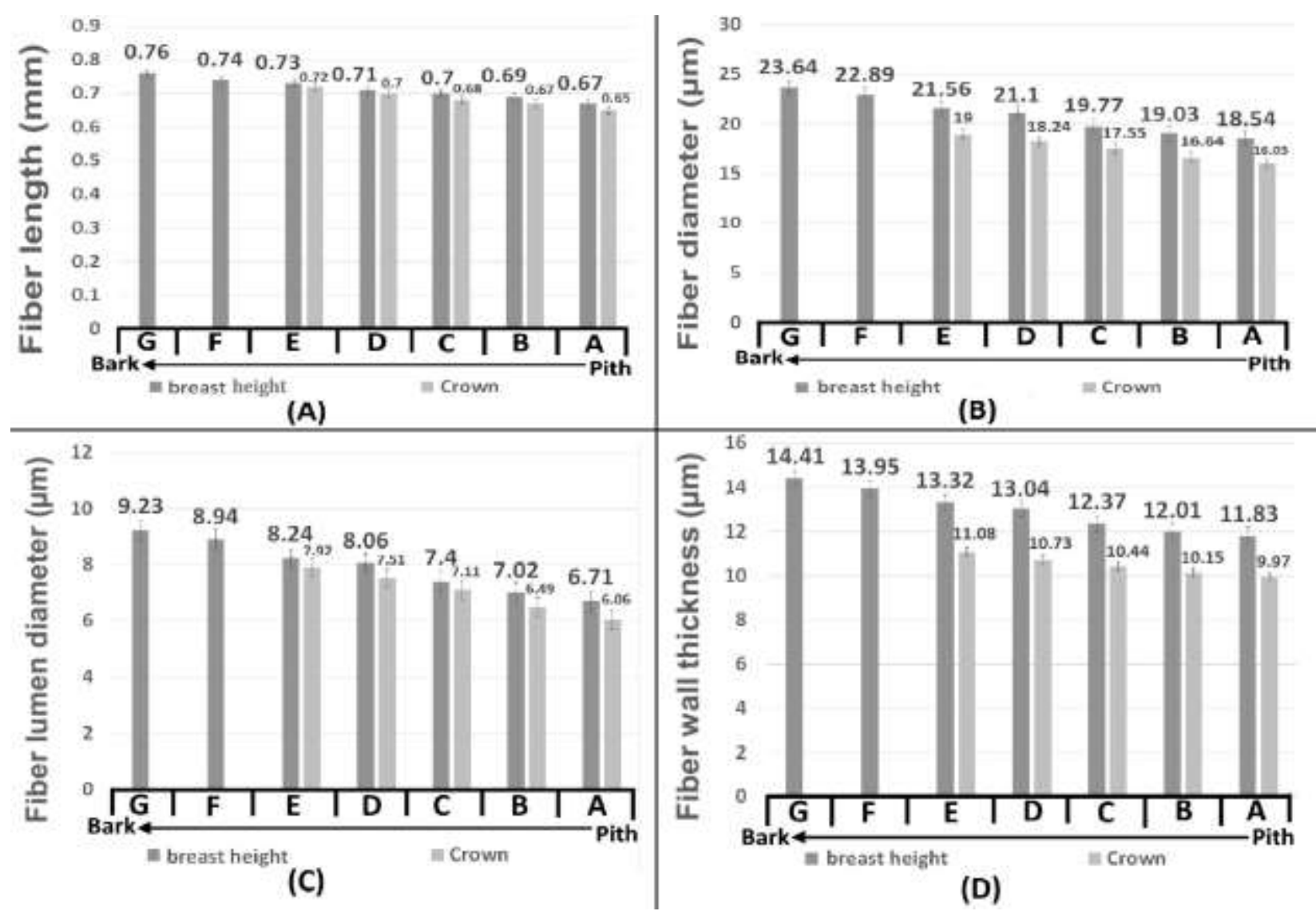

Fig. 7. Changes in (A) fiber length, $(B)$ fiber diameter, $(C)$ fiber lumen diameter, and (D) cell wall thickness of $C$. sinensis trees tree in different parts of the tree stem

\section{Physical Properties}

With increasing height from breast height to tree crown, the oven-dry density and basic density decreased. The greatest oven-dry density and basic density at breast height in the bark area (sample G) were $0.81 \mathrm{~g} / \mathrm{cm}^{3}$ and $0.78 \mathrm{~g} / \mathrm{cm}^{3}$, respectively. The lowest ovendry density and basic density were observed in the area of the crown near the pith (sample A): $0.6 \mathrm{~g} / \mathrm{cm}^{3}$ and $0.57 \mathrm{~g} / \mathrm{cm}^{3}$, respectively (Fig. 8). As shown in Fig. 8, the density increased from the pith to the bark.

The greater density in the bark area than in the area of the pith indicated the presence of juvenile wood in the area of the pith that was less dense. Meanwhile, in the area of the bark, the presence of mature wood increased the density. Furthermore, the ovendry density and basic density decreased along the tree from breast height to the top of the tree. This result can be attributed to the volume of juvenile wood in the crown of the tree (Efhami and Saraeyan 2009). Wood density is a very important factor for all wood industry mills. Wood density is correlated with the final use of wood. In the particle board, OSB 
and PSL, wood density affects the strength of produced boards. This is because as the wood density decreases, compression ratio increases. In the particle board industry, the lower the density of species due to the increased compression ratio during pressing, the higher the strength of the produced boards. By measuring the density of the $C$. sinensis tree in different parts of the tree, the authors came to the conclusion that the upper part of the tree (near the crown) is more suitable than the down part of the tree (breast height) due to its lower density applied to particle board industry.

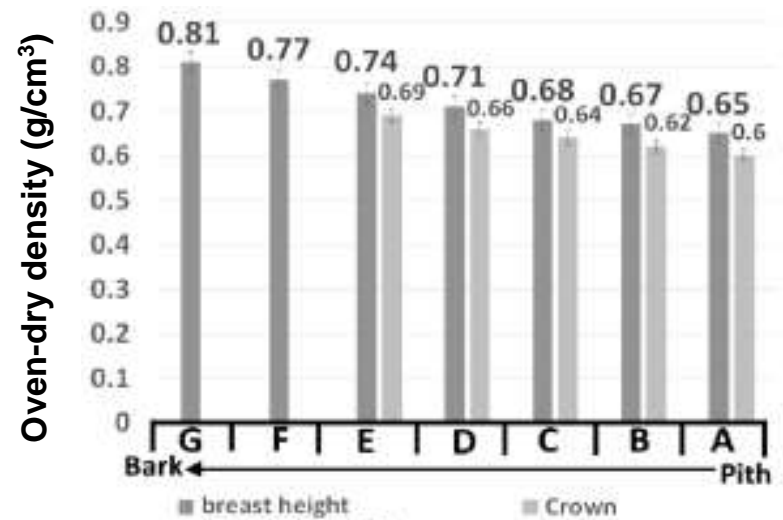

(A)

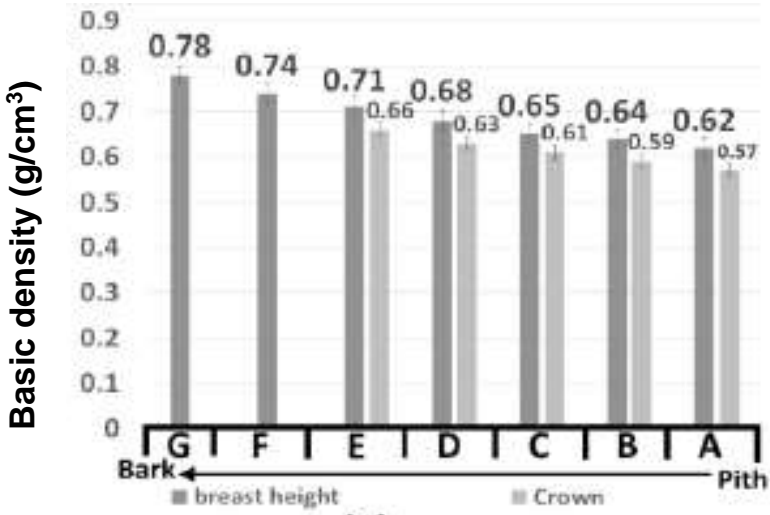

(B)

Fig. 8. Changes in (A) oven-dry density and (B) basic density in different parts of the tree

\section{CONCLUSIONS}

1. With increasing tree length from breast height to tree crown, fiber length, fiber lumen diameter, fiber diameter, and cell wall thickness decreased. Meanwhile, these properties increased from tree pith to tree bark.

2. The oven-dry density and basic density increased radially from tree pith to tree bark and decreased longitudinally from the bottom of the tree to the crown.

3. Anatomical examination of the wood near the bark of the Citrus sinensis tree indicated that this species is a diffuse porous hardwood, with indistinct growth rings, simple perforation plates, alternate intervessel pits, and axial parenchyma in bands more than three cells wide. 


\section{REFERENCES CITED}

Adamopoulos, S., and Voulgaridis, E. (2002). "Within-tree variation in growth rate and cell dimensions in the wood of black locust (Robinia pseudoacacia)," IAWA Journal 23(2), 191-199. DOI: 10.1163/22941932-90000297

Aliabadi, M., Akbarpour, I., Saraeian, A. R., and Roushenasan, J. (2011). "Biometrical properties of hornbeam fibers from Astara," Iranian Journal of Wood and Paper Science Research 26(3), 535-544. DOI: 10.22092/IJWPR.2011.117234

Efhami, D., and Saraeyan, A. R. (2009). "Evaluation of anatomical and physical properties of juvenile/mature wood of Populus alba and Populus $\times$ euramericana," Iranian Journal of Wood and Paper Science Research 24(1), 134-147. DOI: 10.22092/IJWPR.2009.117363

Eromosele, O. J. (2016). "Anatomical study of the trunk of Citrus sinensis with respect to vessels and rays," European Journal of Botany, Plant Sciences and Phytology 3(3), 19.

Franklin, G. L. (1945). "Preparation of thin sections of synthetic resins and wood-resin composites, and a new macerating method for wood," Nature 155(3924), 51. DOI: $10.1038 / 155051 \mathrm{a} 0$

Hassanpoor Tichi, A., and Rezanezhad Divkolae, M. (2019). “Anatomical, physical and biometric properties of Ficus carica wood in longitudinal and transverse direction of tree stem," Iranian Journal of Wood and Paper Science Research 34(2), 228-241. DOI: 10.22092/IJWPR.2019.127323.1564

ISO 13061-2 (2014). "Physical and mechanical properties of wood. Test methods for small clear wood specimens. Determination of density for physical and mechanical tests," International Organization for Standardization, Geneva, Switzerland.

Mahdavi, S., Hosseinzadeh, A., Familian, H., and Habibi, M. (2004). "Investigation on relation of fiber dimension and wood density with age and ring width in $E$. camaldulensis Dehnh.," Iranian Journal of Wood and Paper Research 19(1), 69-98. DOI: 10.22092/IJWPR.2004.117562

Marsoem, S. N., Haryanti, E., and Lukmandaru, G. (2002). "Radial and axial variation in the fibre dimensions and cell proportion of auri (Acacia auriculiformis) wood grown in the community forest," in: The Fifth Pacific Regional Wood Anatomy Conference, Yogyakarta, Indonesia, pp. 9-14.

Nosrati, B., Hagh Panah, M., Masoudifar, M., and Dorostkar, A. (2015). "Comparing the microscopic properties of wood near the pith and bark of Dalbergia sissoo in ShoshDanial," Iranian Journal of Wood and Paper Science Research 30(3), 351-361. DOI: 10.22092/IJWPR.2015.12930

Olife, I. C., Ibeagha, O. A., and Onwualu, A. P. (2015). "Citrus fruits value chain development in Nigeria," Journal of Biology, Agriculture and Healthcare 5(4), 36-47.

Parsapajouh, D., and Schweingruber, F. H. (2001). "Different stage of the procedure," in: Atlas of the Woods of North of Iran, Tehran University Publications, Tehran, Iran.

Saeedi, S., Bahmani, M., Kool, F., Iranmanesh, Y., and Abbasi, M. (2017). "Investigation on physical, chemical and biometrical properties of Persian oak (Quercus brantii Lindl.) (Case study: Lordegan township)," Journal of Wood \& Forest Science and Technology 24(3), 171-182. DOI: 10.22069/JWFST.2017.13170.1676

Vogel, S. (2003): Comparative Biomechanics: Life's Physical World, Princeton University Press, 580 pp.

Wheeler, E. A., Baas, P., and Gasson, P. E. (eds.) (1989). "IAWA list of microscopic 
features for hardwood identification," IAWA Bulletin New Series 10(3), 219-332.

Zobel, B. J., and Sprague, J. R. (1998). "Predictions of mature and total tree wood properties from juvenile wood," in: Juvenile Wood in Forest Trees, Springer-Verlag, Berlin, Germany, pp. 173-187. DOI: 10.1007/978-3-642-72126-7_6

Zobel, B. J., and van Buijtenen, J. P. (1989). "Variation within and among trees," in: Wood Variation: Its Causes and Control, Springer-Verlag, Berlin, Germany, pp. 72131. DOI: 10.1007/978-3-642-74069-5_3

Article submitted: March 25, 2020; Peer review completed: May 16, 2020; Revised version received: May 25, 2020; Accepted: May 30, 2020; Published: June 3, 2020. DOI: 10.15376/biores.15.3.5696-5709 